\title{
VIABILITAS BENIH DAN VIGOR KECAMBAH EMPAT GENOTIPE SORGUM (Sorghum bicolor [L.] Moench) PASCA PENYIMPANAN 16 BULAN
}

\section{SEED VIABILITY AND VIGORS OF FOUR GENOTYPES OF SORGUM (Sorghum bicolor [L.] Moench) POST STORAGE 16 MONTHS}

\author{
M. Afriansyah*, Ermawati, Eko Pramono, dan Yayuk Nurmiaty \\ Jurusan Agroteknologi, Fakultas Pertanian, Universitas Lampung \\ J1 Sumantri Brojonegoro 1, Bandar Lampung 35145, Indonesia \\ *Email:m.afriansyah9lite@gmail.com
}

\begin{abstract}
Sorghum is a cereal plant that has potential as a source of carbohydrates and food. The supply of quality seeds is an effort to support food diversification. One of the criteria for quality seeds is that the seeds still have high viability and vigor after the storage period. The purpose of this study was to determine the viability of seed and vigor sprouts of four sorghum genotypes after storage for 16 months at a storage temperature of $\pm 26^{\circ} \mathrm{C}$ and $\pm 18^{\circ} \mathrm{C}$. This study consisted of two unstructured single treatment experiments with four sorghum genotypes, namely Super 1 (g1), P/F-5-193C (g2), GH 3 (g3), and GH 10 (g4). Experiment I used a storage room temperature of $\pm 26^{\circ} \mathrm{C}\left(T_{1}\right)$, and experiment II used a storage room temperature of $\pm 18^{\circ} \mathrm{C}\left(T_{2}\right)$. This research use a completely randomized block design with 3 replications. The results showed that storage in experiment I had a storage temperature of $\pm 26^{\circ} \mathrm{C}$ and experiment II for storage temperature of $\pm 18^{\circ} \mathrm{C}$ viability and vigor of seed genotype P/F-5-193C and GH 10 were higher than for other genotypes. These results indicated total normal sprout, germination speed, strong normal sprout, normal shoot sprout length, normal sprout primary root length, and normal sprouts dry weight.
\end{abstract}

Keywords: Genotype, seed viability, seed vigor, sorghum seed, storage temperature.

\begin{abstract}
ABSTRAK
Sorgum merupakan tanaman serealia yang memiliki potensi sebagai sumber karbohidrat dan bahan pangan. Penyediaan benih bermutu merupakan upaya untuk mendukung diversifikasi pangan. Salah satu kriteria benih bermutu adalah benih yang tetap mempunyai viabilitas dan vigor yang tinggi setelah periode penyimpanan. Tujuan penelitian ini adalah untuk megetahui viabilitas benih dan vigor kecambah empat genotipe sorgum pasca penyimpanan 16 bulan pada kondisi suhu simpan $\pm 26^{\circ} \mathrm{C}$ dan $\pm 18^{\circ} \mathrm{C}$. Penelitian ini terdiri dari dua percobaan perlakuan tunggal tidak terstruktur dengan empat genotipe sorgum yaitu Super $1\left(\mathrm{~g}_{1}\right), \mathrm{P} / \mathrm{F}-5-193 \mathrm{C}\left(\mathrm{g}_{2}\right), \mathrm{GH} 3\left(\mathrm{~g}_{3}\right)$, dan GH $10\left(\mathrm{~g}_{4}\right)$. Percobaan I menggunakan suhu ruang simpan $\pm 26^{\circ} \mathrm{C}\left(\mathrm{T}_{1}\right)$, dan Percobaan II menggunakan suhu ruang $\operatorname{simpan} \pm 18^{\circ} \mathrm{C}\left(\mathrm{T}_{2}\right)$. Penelitian ini menggunakan Rancangan Kelompok Teracak Sempurna sebanyak 3 ulangan. Hasil penelitian menunjukkan bahwa penyimpanan pada percobaan I suhu simpan $\pm 26^{\circ} \mathrm{C}$ dan percobaan II suhu simpan $\pm 18^{\circ} \mathrm{C}$ viabilitas dan vigor benih Genotipe P/F-5-193C dan GH 10 paling tinggi dari pada genotipe
\end{abstract}


lainnya. Hasil ini ditunjukkan kecambah normal total, kecepatan perkecambahan, kecambah normal kuat, panjang tajuk kecambah normal, panjang akar primer kecambah normal, dan bobot kering kecambah normal.

Kata kunci: Benih sorgum, genotipe, kecambah, suhu simpan, viabilitas benih, vigor.

\section{PENDAHULUAN}

Sorgum merupakan salah satu tanaman serealia yang memiliki potensi sebagai sumber karbohidrat dan bahan pangan. Sorgum memiliki kandungan karbohidrat yang cukup potensial karena kandungan karbohidratnya cukup tinggi sekitar 73,0 gram dan 332 kalori sera nutrisi lainnya seperti protein, lemak, kalsium, fosfor, zat besi, vitamin B1 dan air (Rukmana dan Oesman, 2005). Sorgum memiliki potensi lain yang cukup luas seperti pangan alternatif dan pakan ternak. Sorgum juga dapat dimanfaatkan sebagai solusi pangan alternatif dalam program diversifikasi pangan.

Upaya memenuhi kebutuhan pangan, pakan dan industri yang terus meningkat, pengembangan sorgum merupakan salah satu alternatif yang dapat dipilih karena didukung oleh kondisi agroekologis dan ketersediaan lahan yang cukup luas. Penggunaan benih bermutu sangat dibutuhkan karena benih bermutu adalah benih yang tetap mempunyai viabilitas dan vigor yang tinggi setelah periode penyimpanan.

Penyimpanan benih merupakan salah satu upaya dalam mempertahankan viabilitas dan vigor benih pada periode simpan tertentu. Faktor yang dapat mempengaruhi viabilitas benih yaitu faktor eksternal dan faktor internal. Faktor eksternal yaitu kondisi lingkungan pada saat memproduksi benih, saat panen, pengolahan, penyimpanan, dan lingkungan tempat pengujian benih. Kondisi tersebut seperti kemasan benih, suhu, komposisi gas, dan kelembapan ruang simpan. Faktor internal yaitu sifat genetik benih, kondisi kulit benih, dan kadar air benih. Selama penyimpanan benih mengalami kemunduran benih secara alami.

Suhu merupakan salah satu faktor yang sangat menentukan kemunduran benih selama periode simpan. Penyimpanan benih pada suhu rendah memiliki daya berkecambah lebih tinggi dari pada disimpan pada suhu tinggi. Suhu ruang simpan yang aman dapat memperlambat laju kemunduran benih. Hasil penilitian Azadi dan Younesi (2013) menunjukkan bahwa benih sorgum yang disimpan pada suhu ruang $25^{\circ} \mathrm{C}$ dengan kadar air awal 14\% memiliki daya berkecambah $45 \%$ setelah disimpan selama 6 bulan lebih rendah dari suhu ruang $15^{\circ} \mathrm{C}$ yang memiliki daya berkecambah $50 \%$.

Sorgum memiliki banyak genotipe dan memiliki sifat genetik berbeda yang dapat dibedakan dari ciriciri khas dan bentuk tanaman. Cirikhas tersebut adalah bentuk tanaman, tinggi tanaman, jumlah anakan, ketahanan terhadap hama penyakit, ketahanan kondisi lahan, kerebahan, rasa, umur panen, dan kemampuan untuk berproduksi dan menghasilkan benih kembali untuk dijadikan bahan perbanyakan tanaman untuk musim tanam selanjutnya. Hasil penelitian Hakim (2017) menunjukkan bahwa mutu benih genotipe P/ F-5-193C lebih baik jika dibandingkan dengan genotipe Super 1, ditunjukkan pada tingkat kekerasan benih, jumlah benih pertanaman, dan bobot benih pertanaman. Tujuan penelitian ini adalah untuk megetahui viabilitas benih dan vigor kecambah empat 
genotipe sorgum pasca penyimpanan 16 bulan pada kondisi suhu simpan $\pm 26^{\circ} \mathrm{C}$ dan $\pm 18^{\circ} \mathrm{C}$.

\section{BAHAN DAN METODE}

Penelitian ini dilakukan di Laboratorium Benih dan Pemuliaan Tanaman Fakultas Pertanian Universitas Lampung dalam periode waktu Februari 2017 sampai Juni 2018. Bahan yang digunakan dalam penelitian ini adalah benih sorgum genotipe SUPER-1, P/F-5-193C, GH 3, dan GH 10 dengan kadar air awal 8\% yang dipanen dari penanaman di Desa Tulung Agung, Kecamatan Gading Rejo, Kabupaten Pringsewu pada bulan januari 2017, aquades, kertas merang, kertas $\mathrm{CD}$, plastik polyetilen (klip), karet gelang, label, dan air. Alat yang digunakan dalam penelitian ini adalah ruang simpan dengan suhu kamar $\left( \pm 26^{\circ} \mathrm{C}\right.$ dan $\mathrm{RH} 60$ $70 \%)$, pendingin udara (AC) dengan suhu $\left( \pm 18^{\circ} \mathrm{C}\right.$ dan RH 50-58\%), strapless, gunting, alat tulis, alat pengempa kertas, Germinator tipe IPB 73 2A/2B, alat penghitung benih (seed counter) tipe Seedburrow, timbangan elektrik tipe Scount Pro, alat pengukur kadar air dengan metode tidak langsung (moisture tester), alat pembersih benih (seed blower), oven, dan desikator. Penelitian ini terdiri dari dua percobaan perlakuan tunggal tidak terstruktur dengan empat genotipe sorgum yaitu Super $1\left(g_{1}\right), P / F-5-193 C\left(g_{2}\right)$, GH $3\left(\mathrm{~g}_{3}\right)$, dan $\mathrm{GH} 10\left(\mathrm{~g}_{4}\right)$. Rancangan percobaan menggunakan rancangan kelompok teracak sempurna (RKTS) yang dilakukan sebanyak tiga ulangan. Percobaan I menggunakan suhu ruang simpan $\pm 26^{\circ} \mathrm{C}$ $\left(\mathrm{T}_{1}\right)$, dan percobaan II menggunakan suhu ruang $\operatorname{simpan} \pm 18^{\circ} \mathrm{C}\left(\mathrm{T}_{2}\right)$. Data yang telah diperoleh, diuji homogenitas ragamnya dengan menggunakan $\mathrm{Uji}$ Bartlett dan kemenambahan data diuji dengan Uji Tukey, bila kedua asumsi terpenuhi data dianalisis ragam. Pemisahan nilai tengah antar perlakuan diuji dengan Uji Beda Nyata Jujur (BNJ) pada taraf á 5\%.

Tabel 1. Ringkasan hasil analisis ragam pengaruh genotipe sorgum pada viabilitas dan vigor kecambah benih di suhu ruang simpan berbeda.

\begin{tabular}{|c|c|c|}
\hline \multirow{2}{*}{ Variabel Pengamatan } & \multicolumn{2}{|c|}{ Signifikasi } \\
\hline & Suhu $\pm 26^{\circ} \mathrm{C}$ & Suhu $\pm 18^{\circ} \mathrm{C}$ \\
\hline \multicolumn{3}{|l|}{ Viabilitas Benih } \\
\hline Kecepatan Perkecambahan & $*$ & * \\
\hline Kecambah Normal Total & * & * \\
\hline Kadar Air & $\operatorname{tn}$ & tn \\
\hline Daya Hantar Listrik & tn & tn \\
\hline \multicolumn{3}{|l|}{ Vigor Kecambah } \\
\hline Kecambah Normal Kuat & $*$ & $*$ \\
\hline Panjang Tajuk Kecambah Normal & tn & * \\
\hline Panjang Akar Primer Kecambah Normal & tn & * \\
\hline Bobot Kering Kecambah Normal & tn & $*$ \\
\hline
\end{tabular}

Keterangan: * = Berbeda pada $\alpha 5 \%$, tn $=$ Tidak Berbeda pada $\alpha 5 \%$ 


\section{HASIL DAN PEMBAHASAN}

\section{Hasil penelitian}

Berdasarkan penelitian yang telah dilakukan maka diperoleh hasil penelitian yang menunjukkan bahwa pada percobaan I suhu simpan $\pm 26^{\circ} \mathrm{C}$, empat genotipe sorgum menghasilkan kecepatan perkecambahan, kecambah normal total, dan kecambah normal kuat berbeda. Pada percobaan II suhu simpan $\pm 18^{\circ} \mathrm{C}$, empat genotipe sorgum menghasilkan kecepatan perkcambahan, kecambah normal total, kecambah normal kuat, panjang tajuk kecambah normal, panjang akar primer kecambah normal, dan bobot kering kecambah normal berbeda (Tabel 1). Hasil penelitian menunjukkan bahwa pada percobaan I suhu simpan $\pm 26^{\circ} \mathrm{C}$, genotipe P/F-5-

Tabel 2. Kecepatan perkecambahan empat genotipe sorgum pada suhu ruang simpan berbeda.

\begin{tabular}{ccc}
\hline \multirow{2}{*}{ Genotipe } & \multicolumn{2}{c}{ Suhu Simpan } \\
\cline { 2 - 3 } & $\pm 26^{\circ} \mathrm{C}$ & $\pm 18^{\circ} \mathrm{C}$ \\
\hline Super 1 & $11,87 \mathrm{~b}$ & $25,89 \mathrm{~b}$ \\
P/F-5-193C & $18,53 \mathrm{a}$ & $36,33 \mathrm{a}$ \\
GH 3 & $1,93 \mathrm{c}$ & $24,53 \mathrm{~b}$ \\
GH 10 & $18,49 \mathrm{a}$ & $32,76 \mathrm{a}$ \\
\hline BNJ 0,05 & 3,37 & 8,07 \\
\hline
\end{tabular}

Keterangan : Dua nilai tengah diikuti huruf yang sama tidak berbeda berdasarkan uji BNJ pada taraf 5\%.

Tabel 3. Kecambah normal total empat genotipe sorgum pada suhu ruang simpan berbeda.

\begin{tabular}{ccc}
\hline \multirow{2}{*}{ Genotipe } & \multicolumn{2}{c}{ Suhu Simpan } \\
\cline { 2 - 3 } & $\pm 26^{\circ} \mathrm{C}$ & $\pm 18^{\circ} \mathrm{C}$ \\
\hline Super 1 & $34,67 \mathrm{~b}$ & $69,33 \mathrm{bc}$ \\
P/F-5-193C & $58,67 \mathrm{a}$ & $88,00 \mathrm{a}$ \\
GH 3 & $6,67 \mathrm{c}$ & $65,67 \mathrm{c}$ \\
GH 10 & $53,33 \mathrm{a}$ & $82,67 \mathrm{ab}$ \\
\hline BNJ 0,05 & 8,22 & 16,72 \\
\hline
\end{tabular}

Keterangan : Dua nilai tengah diikuti huruf yang sama tidak berbeda berdasarkan uji BNJ pada taraf 5\%.
193C dan GH 10 lebih tinggi jika dibandingkan dengan Genotipe Super 1 dan GH3, dapat dilihat dari variabel kecambah normal total (Tabel 3), kecepatan perkecambahan (Tabel 2), dan kecambah normal kuat (Tabel 4). Percobaan II suhu simpan $\pm 18^{\circ} \mathrm{C}$, Genotipe P/F-5-193C dan GH 10 menghasilkan kecepatan perkecambahan paling tinggi sebesar $36,33 \%$ dan 3,76 $\%$ (Tabel 2), kecambah normal total sebesar 88,00\% dan 82,67 \% (Tabel 3). Percobaan II suhu simpan $\pm 18^{\circ} \mathrm{C}$ pada genotipe $\mathrm{P} / \mathrm{F}-5-193 \mathrm{C}$ juga menghasilkan kecambah normal kuat paling tinggi sebesar 83,00\% (Tabel 4), panjang tajuk kecambah normal sebesar 13,13 \% (Tabel 5), panjang akar primer kecambah normal sebesar 12,36\% (Tabel 6), dan bobot kering kecambah normal sebesar 9,27 \% (Tabel 7).

Tabel 4. Kecambah normal kuat empat genotipe sorgum yang disimpan pada suhu ruang simpan berbeda transformasi.

\begin{tabular}{ccc}
\hline \multirow{2}{*}{ Genotipe } & \multicolumn{2}{c}{ Suhu Simpan } \\
\cline { 2 - 3 } & $\pm 26^{\circ} \mathrm{C}$ & $\pm 18^{\circ} \mathrm{C}$ \\
\hline Super 1 & $42,67 \mathrm{~b}$ & $62,67 \mathrm{~b}$ \\
P/F-5-193C & $61,67 \mathrm{a}$ & $83,00 \mathrm{a}$ \\
GH 3 & $21,67 \mathrm{c}$ & $43,00 \mathrm{c}$ \\
GH 10 & $41,33 \mathrm{~b}$ & $61,33 \mathrm{bc}$ \\
\hline BNJ 0,05 & 16,57 & 18,53 \\
\hline
\end{tabular}

Keterangan : Dua nilai tengah diikuti huruf yang sama tidak berbeda berdasarkan uji BNJ pada taraf 5\%.

Tabel 5. Panjang tajuk kecambah normal empat genotipe sorgum yang disimpan pada suhu ruang simpan berbeda.

\begin{tabular}{clc}
\hline \multirow{2}{*}{ Genotipe } & \multicolumn{3}{c}{ Suhu Simpan } \\
& $\pm 26^{\circ} \mathrm{C}$ & $\pm 18^{\circ} \mathrm{C}$ \\
\hline Super 1 & $11,17 \mathrm{a}$ & $14,32 \mathrm{a}$ \\
P/F-5-193C & 9,33 a & $13,13 \mathrm{a}$ \\
GH 3 & 8,87 a & $11,48 \mathrm{~b}$ \\
GH 10 & $11,17 \mathrm{a}$ & $10,53 \mathrm{~b}$ \\
\hline BNJ 0,05 & 4,80 & 2,54 \\
\hline
\end{tabular}

Keterangan : Dua nilai tengah diikuti huruf yang sama tidak berbeda berdasarkan uji BNJ pada taraf 5\%. 
Tabel 6. Panjang akar primer kecambah normal empat genotipe sorgum yang disimpan pada suhu ruang simpan berbeda.

\begin{tabular}{ccc}
\hline \multirow{2}{*}{ Genotipe } & \multicolumn{2}{c}{ Suhu Simpan } \\
\cline { 2 - 3 } & $\pm 26^{\circ} \mathrm{C}$ & $\pm 18^{\circ} \mathrm{C}$ \\
\hline Super 1 & $8,41 \mathrm{a}$ & $9,31 \mathrm{~b}$ \\
P/F-5-193C & $9,23 \mathrm{a}$ & $12,36 \mathrm{a}$ \\
GH 3 & $8,95 \mathrm{a}$ & $10,95 \mathrm{ab}$ \\
GH 10 & $10,63 \mathrm{a}$ & $11,03 \mathrm{ab}$ \\
\hline BNJ 0,05 & 3,31 & 2,76 \\
\hline
\end{tabular}

Keterangan : Dua nilai tengah diikuti huruf yang sama tidak berbeda berdasarkan uji BNJ pada taraf 5\%.

Tabel 7. Bobot kering kecambah normal empat genotipe sorgum yang disimpan pada suhu ruang simpan berbeda.

\begin{tabular}{ccc}
\hline \multirow{2}{*}{ Genotipe } & \multicolumn{2}{c}{ Suhu Simpan } \\
\cline { 2 - 3 } & $\pm 26^{\circ} \mathrm{C}$ & $\pm 18^{\circ} \mathrm{C}$ \\
\hline Super 1 & 5,49 a & $7,83 \mathrm{a}$ \\
P/F-5-193C & 6,62 a & $9,27 \mathrm{~b}$ \\
GH 3 & 5,69 a & $7,22 \mathrm{a}$ \\
GH 10 & 7,64 a & $7,85 \mathrm{a}$ \\
\hline BNJ 0,05 & 2,44 & 0,95 \\
\hline
\end{tabular}

Keterangan : Dua nilai tengah diikuti huruf yang sama tidak berbeda berdasarkan uji BNJ pada taraf 5\%.

\section{Pembahasan}

Hasil penelitian menunjukkan bahwa pada percobaan I suhu simpan $\pm 26^{\circ} \mathrm{C}$, genotipe P/F-5193C dan GH 10 menghasilkan viabilitas benih yang lebih tinggi jika dibandingkan dengan Genotipe Super 1 dan GH 3, dapat dilihat dari variabel kecambah normal total (Tabel 3), kecepatan perkecambahan (Tabel 2), dan kecambah normal kuat (Tabel 4) setelah disimpan selama 16 bulan. Hal ini diduga karena faktor internal benih dari genotipe tersebut yang paling baik seperti perbedaan materi genetik, kondisi kulit, dan respon yang berbeda dari genotipe lainnya. Hal ini sejalan dengan hasil penelitian Moyo et al.,(2015) yang menyatakan bahwa genotipe sorgum memberikan respon yang berbeda berdasarkan uji kecepatan
Tabel 8. Kadar air benih empat genotipe sorgum yang disimpan pada suhu ruang simpan berbeda.

\begin{tabular}{ccc}
\hline \multirow{2}{*}{ Genotipe } & \multicolumn{3}{c}{ Suhu Simpan } \\
\cline { 2 - 3 } & $\pm 26^{\circ} \mathrm{C}$ & $\pm 18^{\circ} \mathrm{C}$ \\
\hline Super 1 & 9,47 a & 9,77 a \\
P/F-5-193C & 9,37 a & $10,07 \mathrm{a}$ \\
GH 3 & 9,27 a & $9,53 \quad \mathrm{a}$ \\
GH 10 & 8,93 a & $9,63 \mathrm{a}$ \\
\hline BNJ 0,05 & 0,86 & 1,12
\end{tabular}

Keterangan : Dua nilai tengah diikuti huruf yang sama tidak berbeda berdasarkan uji BNJ pada taraf 5\%.

Tabel 9. Daya hantar listrik empat genotipe sorgum yang disimpan pada suhu ruang simpan berbeda.

\begin{tabular}{ccc}
\hline \multirow{2}{*}{ Genotipe } & \multicolumn{3}{c}{ Suhu Simpan } \\
\cline { 2 - 3 } & $\pm 26^{\circ} \mathrm{C}$ & $\pm 18^{\circ} \mathrm{C}$ \\
\hline Super 1 & 108,53 a & $91,37 \quad \mathrm{a}$ \\
P/F-5-193C & 109,47 a & 88,60 a \\
GH 3 & 165,00 a & 148,77 a \\
GH 10 & 126,97 a & 105,73 a \\
\hline BNJ 0,05 & 178,48 & 112,19 \\
\hline
\end{tabular}

Keterangan : Dua nilai tengah diikuti huruf yang sama tidak berbeda berdasarkan uji BNJ pada taraf 5\%.

perkecambahan dan kecambah normal total karena benih secara genetik tampil beda saat terkena kondisi yang sama.

Hasil penelitian menunjukkan bahwa genotipe P/F-5-193C dan GH 10 menghasilkan kecepatan perkecambahan (Tabel 2) lebih tinggi diantara genotipe Super 1 dan GH 3 sehingga genotipe tersebut memiliki viabilitas yang tinggi dari genotipe Super 1 dan GH 3 setelah disimpan selama 16 bulan pada suhu ruang simpan $\pm 26^{\circ} \mathrm{C}$ ditunjukkan pada hasil keecambah normal total sebesar 58,67 \% untuk genotipe P/F-5193C dan 53,33 \% untuk genotipe GH 10. Hal ini sejalan dengan Sadjad (1993) yang menyatakan bahwa benih yang memiliki kecepatan perkecambahan tinggi memiliki viabilitas yang tinggi. Viabilitas benih 
tinggi memiliki daya tumbuh $>80 \%$, viabilitas benih sedang memiliki daya tumbuh 60-80\%, dan viabilitas benih rendah memiliki daya tumbuh $<60 \%$.

Pada percobaan I dengan suhu simpan $\pm 26^{\circ} \mathrm{C}$ viabilitas benih masuk dalam kelas viabilitas rendah karena keempat genotipe menghasilkan daya kecambah $<60 \%$. Hal ini dikarenakan pada kondisi suhu simpan $\pm 26^{\circ} \mathrm{C}$ memiliki temperatur yang tinggi mengakibatkan terjadinya penurunan viabilitas benih yang ditandai dengan penurunan daya kecambah. Sadjad (1993) menyatakan bahwa daya berkecambah merupakan tolak ukur viabilitas potensial yang merupakan simulasi dari kemampuan benih untuk tumbuh dan berproduksi normal dalam kondisi optimum.

Penurunan daya kecambah tersebut disebabkan karena benih yang disimpan pada suhu $\pm 26^{\circ} \mathrm{C}$ mengalami respirasi terus menerus karena enzim-enzim yang ada di dalam benih menjadi akif. Respirasi ini menyebabkan terjadinya perombakan cadangan makanan dalam benih. Semakin lama proses respirasi ini terjadi, semakin banyak pula cadangan makanan benih yang digunakan. Hal ini akan menyebabkan cadangan makanan habis dan mengakibatkan bila benih ditanam akan mengalami kemunduran viabilitas yang ditunjukkan dengan turunnya daya berkecambah sebab benih yang sudah kehabisan cadangan makanan tidak mempunyai energi lagi untuk berkcambah.

Genotipe P/F-5-193C dan GH 10 diduga mampu bertahan pada kondisi lingkungan dengan suhu $\pm 26^{\circ} \mathrm{C}$ sehingga genotipe tersebut menjadi yang paling baik viabilitasnya dibandingkan dengan genotipe lain, sedangkan genotipe $\mathrm{GH} 3$ tidak mampu bertahan pada kondisi tersebut dan menghasilkan viabilitas yang paling buruk. Hal ini ditunjukkan dengan genotipe GH 3 menghasilkan kecepatan perkecambahan paling kecil sebesar 1,93\%, kecambah normal total sebesar 6,67 $\%$, dan kecambah normal kuat 21,67\% (Tabel 2).

Hasil penelitian menunjukkan bahwa pada percobaan II suhu simpan $\pm 18^{\circ} \mathrm{C}$, Genotipe $\mathrm{P} / \mathrm{F}-5$ 193C dan GH 10 memiliki viabilitas yang paling tinggi, dapat dilihat pada variabel kecepatan perkecambahan sebesar 36,33\% dan 3,76\% (Tabel 2), kecambah normal total sebesar $88,00 \%$ dan $82,67 \%$ (Tabel 3). Hal ini diduga karena faktor suhu dan kelembapan pada ruang simpan $\pm 18^{\circ} \mathrm{C}$. Diketahui bahwa suhu rendah lebih baik dari pada suhu tinggi untuk penyimpanan benih. Hal ini sesuai dengan hasil penelitian Anggraini (2017), bahwa benih sorgum yang disimpan pada ruang simpan $\pm 18^{\circ} \mathrm{C}$ selama 12 bulan menyebabkan persentase kecambah normal total menjadi $86,00 \%$ turun dari semula $94,50 \%$.

Percobaan II suhu simpan $\pm 18^{\circ} \mathrm{C}$ pada genotipe P/F-5-193C juga menghasilkan vigor benih yang tinggi, ditunjukkan pada variabel kecambah normal kuat sebesar 83,00\% (Tabel 4), panjang tajuk kecambah normal sebesar 13,13\% (Tabel 5), panjang akar primer kecambah normal sebesar 12,36\% (Tabel 6), dan bobot kering kecambah normal sebesar 9,27 \% (Tabel 7). Hal ini disebebkan karena benih yang disimpan pada suhu rendah $\pm 18^{\circ} \mathrm{C}$ aktifitas enzim yang ada di dalam benih menjadi nonaktif sehingga tidak terjadi respirasi, karena tidak terjadi respirasi maka tidak terjadi pula perombakan cadangan makanan, sehingga cadangan makanan yang ada di dalam benih masih utuh, hal inilah yang menyebabkan viabilitas benih tidak menurun sehingga pada kondisi tersebut viabilitas 
dan vigor benih dapat dipertahankan lebih lama. Hal ini sesuai dengan pernyataan Purwanti (2004), bahwa pada suhu rendah respirasi berjalan lambat sehingga vigor dapat dipertahankan. Sadjad (1993) menyatakan bahwa kemampuan berkecambah suatu benih berhubungan dengan cadangan makanan yang terkandung dalam benih. Maksum (2018) menyatakan bahwa viabilitas benih sorgum pascasimpan 12 bulan pada suhu rendah lebih tinggi dibandingkan dengan benih yang disimpan pada suhu kamar ditinjukkan oleh variabel kecambah normal total, kecepatan perkecambahan, dan benih mati. Memen dkk. (2012) menyatakan bahwa tingginya suhu menyebabkan semakin tingginya laju respirasi sehingga mempercepat kemunduran benih.

Hasil penelitian menunjukkan bahwa pada percobaan II suhu simpan $\pm 18^{\circ} \mathrm{C}$ Genotipe P/F-5193C dan GH 10 memiliki mutu benih yang masih tinggi dengan persentase daya kecambah benih $>80 \%$ setelah disimpan selama 16 bulan, pada percobaan I suhu simpan $\pm 26^{\circ} \mathrm{C}$ Genotipe P/F-5-193C dan GH 10 memiliki mutu benih yang rendah dengan persentase daya kecambah benih $<60 \%$. Dilihat dari hasil penelitian tersebut percobaan II suhu simpan $\pm 18^{\circ} \mathrm{C}$ lebih baik dari pada percobaan I suhu simpan $\pm 26^{\circ} \mathrm{C}$, namun pada penelitian ini tidak dibuktikan bahwa percobaan II suhu simpan $\pm 18^{\circ} \mathrm{C}$ lebih baik dari pada percobaan I suhu simpan $\pm 26^{\circ} \mathrm{C}$ karena pada penelitian ini tidak dilakukan percobaan mengenai interaksi antara percobaan I $\left( \pm 26^{\circ} \mathrm{C}\right)$ dan percobaan II $\left( \pm 18^{\circ} \mathrm{C}\right)$.

Penyimpanan benih pada suhu $\pm 18^{\circ} \mathrm{C}$ sangat direkomendasikan apabila benih akan disimpan dalam jangka waktu lebih dari 6 bulan karena benih masih mampu untuk berkecambah normal dengan baik. Penyimpanan benih pada suhu $\pm 18^{\circ} \mathrm{C}$ memiliki kekurangan yaitu, biaya yang dibutuhkan untuk membuat ruang penyimpanan dengan suhu $\pm 18^{\circ} \mathrm{C}$ terbilang cukup mahal bila dibandingkan dengan ruang penyimpanan biasa.

\section{KESIMPULAN}

Berdasarkan hasil penelitian dan pembahasan dapat disimpulkan bahwa penyimpanan pada suhu $\pm 26^{\circ} \mathrm{C}$ viabilitas dan vigor benih genotipe $\mathrm{P} / \mathrm{F}-5-193 \mathrm{C}$ dan GH 10 paling tinggi dari pada genotipe lainnya. Hasil ini ditunjukkan kecambah normal total, kecepatan perkecambahan, kecambah normal kuat, dan benih mati paling rendah. Pada penyimpanan suhu $\pm 18^{\circ} \mathrm{C}$ genotipe P/F-5-193C dan GH 10 menghasilkan vigor kecambah paling tinggi dari pada genotipe lainnya. Hasil ini ditunjukkan kecepatan perkecambahan, kecambah normal total, panjang tajuk kecambah normal, panjang akar primer kecambah normal, dan bobot kering kecambah normal.

\section{UCAPAN TERIMA KASIH}

Ucapan terima kasih disampaikan kepada kepala laboratorium benih dan pemuliaan tanaman yang telah memfasilitasi semua kebutuhan dalam pelaksanaan penelitian serta tim penelitian yang telah memberikan motivasi dan bantuan tenaga dalam pelaksanaan penelitian ini, sehingga dapat terlaksana dengan baik dan lancar. 


\section{DAFTAR PUSTAKA}

Anggraini, N. 2017. Pengaruh Lama Simpan pada Viabilitas Benih dan Vigor Kecambah Empat Genotipe Sorgum (Sorghum bicolor [L.] Moench). Skripsi. Universitas Lampung. Lampung. $37 \mathrm{hlm}$.

Azadi, M.S. and E. Younesi. 2013. The effects of storage on germination characteristics and enzyme activity of sorghum seeds. Journal of Stress Physiology \& Biochemistry. 9(4): 289-298.

Hakim, F.A. 2017. Pengaruh Genotipe pada Produksi dan Mutu Benih Sorgum (Sorghum bicolor [L.] Moench) Pascasimpan 3 dan 9 Bulan. Skripsi. Universitas Lampung. Lampung. $31 \mathrm{hlm}$.

Maksum, N.Z. 2018. Pengaruh Suhu dan Genotipe pada Viabilitas Benih Sorgum (Sorghum bicolor [L.] Moench) Pascasimpan 12 Bulan. $43 \mathrm{hlm}$.
Memen, S., M. Endang, dan N.N. Fifin. 2012. Pengaruh Tingkat Kemasakan Buah Metode Ekstraksi Buah, Metode Pengeringan, Jenis Kemasan, dan Lama Penyimpanan pada Mutu Benih Jarak Pagar (Jatropha curous). Jurnal Ilmu Pertanian Indonesia. 18 (2) : 73-78.

Moyo, R., E. Ndlovu, N. Moyo, dan M. Maphosa. 2015. Physiological parameters of seed vigour in ex situ stored sorghum germplasm. $J$. Cereals oilseeds.(6) 6: 31-38.

Purwanti, S. 2004. Kajian Suhu Ruang Simpan terhadap Kualitas Benih Kedelai Hitam dan Kedelai Kuning. Jurnal Imu Pertanian 11 (1): 22-31.

Rukmana, R. dan Y.Y. Oesman. 2005. Usaha Tani Sorgum. Penerbit Kanisius. Jogyakarta.

Sadjad, S. 1993. Dari Benih Kepada Benih. PT Gramedia Widiasarana Indonesia. Jakarta. 